Catherine DE SIENNE, Éric T. de CLERMONT-TONNERRE, (introd.), Les Lettres. I. Lettres au Pape, aux cardinaux et aux évêques

Paris, Éditions du Cerf, 2008, 240 p.

\title{
Raymond Courcy
}

\section{(2) OpenEdition}

\section{Journals}

Édition électronique

URL : http://journals.openedition.org/assr/21545

DOI : $10.4000 /$ assr. 21545

ISSN : $1777-5825$

Éditeur

Éditions de l'EHESS

Édition imprimée

Date de publication : 31 décembre 2009

Pagination : 75-342

ISBN : 978-2-7132-2218-4

ISSN : 0335-5985

Référence électronique

Raymond Courcy, "Catherine de sienne, Éric T. de cleRmont-tonnerre, (introd.), Les Lettres. I. Lettres au

Pape, aux cardinaux et aux évêques », Archives de sciences sociales des religions [En ligne], 148| octobre-décembre 2009, document 148-32, mis en ligne le 27 janvier 2010, consulté le 21 septembre 2020. URL : http://journals.openedition.org/assr/21545 ; DOI : https://doi.org/10.4000/assr.21545

Ce document a été généré automatiquement le 21 septembre 2020.

(C) Archives de sciences sociales des religions 


\title{
Catherine DE SIENNE, Éric T. de CLERMONT-TONNERRE, (introd.), Les Lettres. I. Lettres au Pape, aux cardinaux et aux évêques
}

Paris, Éditions du Cerf, 2008, 240 p.

\author{
Raymond Courcy
}

\section{RÉFÉRENCE}

Catherine DE SIENNE, Éric T. de CLERMONT-TONNERRE, (introd.), Les Lettres. I. Lettres au Pape, aux cardinaux et aux évêques, Paris, Éditions du Cerf, 2008, 240 p.

1 Catherine de Sienne fut proclamée docteur de l'Église universelle par Paul VI, le 4 octobre 1970. Elle vécut au XIV ${ }^{e}$ siècle (1347-1380) simple tertiaire dominicaine. On parle très peu d'elle dans les chroniques de l'époque. Mais au-delà d'une vie mystique très forte, elle eut une production littéraire très abondante. Outre Dialogues et Les Oraisons, son œuvre consiste essentiellement dans les nombreuses lettres qu'elle écrivit, souvent avec l'aide de secrétaires dont le plus connu est Raymond de Capoue. Ce recueil de lettres adressées aux papes et aux évêques est le premier d'une longue série. Suivront prochainement les lettres: aux rois, aux reines et aux politiques; à des laïcs; à sa famille et à ses disciples; aux moines et aux moniales; aux religieux et aux prêtres. Il s'agit de la traduction d'une édition italienne datant de 1987.

2 Ses lettres furent écrites à une période trouble de la vie de l'Église catholique. En effet, la péninsule italienne vivait au rythme de la violence, avec la destructuration des principales villes désormais aux mains d'aventuriers ou de grandes familles bourgeoises. L'argent roi déterminait les rapports sociaux. De nombreuses révoltes populaires éclataient. Le royaume de Naples s'effondrait. Rome n'était plus un lieu sûr. 
Comme par ailleurs, la dynamique politique et économique tournait autour du royaume de France, les papes vinrent s'établir en Avignon dans le comtat Venaissin.

Catherine œuvra alors pour que les papes reviennent à Rome. Ce ne fut pas facile dans la mesure où, à un moment donné, il y eut deux, voire même trois papes... et où, par ailleurs, les mœurs des prélats ecclésiastiques étaient plutôt dépourvues de rigueur morale. Elle écrivit aux deux papes légitimes Grégoire XI et Urbain VI pour les conforter dans leurs tâches en les encourageant à revenir à Rome et à y demeurer. Elle écrivit également aux cardinaux et aux évêques pour qu'ils restent fidèles à ces papes.

On ne peut être que séduit par l'audace, la force et la sagesse de ses propos. Elle osa prendre la parole dans une société cléricale et masculine. Elle indiqua à tous le chemin de la vérité et de la conversion évangélique, s'insurgeant sans cesse contre le péché, le mensonge et l'injustice. Les grandes causes que défendit Catherine de Sienne sont des questions essentielles pour son temps. Elle prêcha pour la fin des violences en appelant à la paix, à l'avènement d'une véritable justice, et proposant une nouvelle croisade contre les infidèles comme exutoire à ces violences. Mais sa préoccupation principale fut, sans aucun doute, un appel constant à une authentique réforme de l'institution religieuse, fustigeant «ces mauvais pasteurs qui infestent et corrompent le jardin de l'Église».

5 Ses lettres se déploient généralement selon une même logique. Au-delà de la première apostrophe: «au nom de Jésus-Christ crucifié et de la très douce Marie», elle rappelle qu'elle est une «indigne et misérable fille.» Elle commence alors par un discours universel se référant par exemple à «l'Agneau immolé», au "Christ crucifié» ou à «l'Amour infini de Dieu». Puis Catherine, avec une facilité étonnante, descend peu à peu vers le particulier et atteint directement le destinataire. Elle ne ménage personne, invitant souvent à «se libérer de la peur» par une «réelle virilité» ou «à triompher de leur malice par votre bonté». Quand il s'agit de l'Amour de Dieu, de la vérité ou de défendre la justice, elle est tranchante comme une lame de couteau; sa parole devient une épée et une flamme. Elle ne craint jamais de dire la vérité aux plus hautes autorités et ses invectives nous font frémir, habitués que nous sommes à un autre langage. Elle jouit d'une liberté de parole sans pareille, n'hésitant pas à s'adresser à Grégoire XI en ces termes: «Oh! Mon très saint et très doux papa.» Par ailleurs «il y a chez Catherine une grande richesse d'images et un art de sculpter ses pensées; son éloquence s'élève parfois si haut, avec une telle ardeur, une telle fougue qu'elle devient poésie, comme si elle cherchait à former des vers.»(G. Papini). Et elle conclut enfin par un soupir féminin: «doux Jésus, Jésus Amour».

6 Aujourd'hui, depuis le concile Vatican II, les laïcs sont appelés à prendre de plus en plus de responsabilités dans l'Église. Par ailleurs, les pratiques centrales du pouvoir romain sont facilement critiquées. La lecture de ces lettres peut être très instructive. L'œuvre de Catherine de Sienne ne peut que susciter de l'intérêt... et peut-être des vocations! 